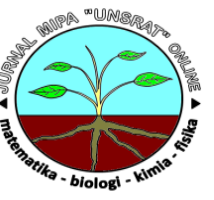

\title{
Isolasi dan Karakterisasi Barcode DNA Tanaman Nusa indah putih (Mussaenda frondosa) Berdasarkan Gen matK
}

\section{Jein Damanisa, Lidya Irma Momuata, Meiske S. Sangia, Maureen Kumaunanga*}

aJurusan Kimia, FMIPA, Unsrat, Manado

\section{KATA KUNCI}

tanaman nusa indah putih matk

Barcode DNA

in-silico

\begin{abstract}
A B S TR A K
Telah dilakukan penelitian untuk menentukan urutan nukleotida dari barcode DNA tanaman Nusa indah putih berdasarkan gen matK dan mengkarakterisasi matK tanaman nusa indah putih dengan analisis insilico. Isolasi DNA dari tanaman Nusa indah putih telah dilakukan berdasarkan manual prosedur dari InnuPrep Plant DNA kit yang dilanjutkan dengan amplifikasi dengan metode Polymerase Chain Reaction (PCR) menggunakan primer forward matK-1RKIM-f dan primer reverse matK-3FKIM-r kemudian dielektroforesis dan disekuensing. Sekuensing tanaman Nusa indah putih menghasilkan kromatogram yang berkualitas tinggi, dengan panjang sekuens 843 bp. Hasil Analisis in-silico menunjukan matk tanaman nusa indah putih bersifat basa, stabil, dan berinteraksi baik dengan air.

A B S T R A C T

A study to determine the nucleotide sequence of the DNA barcode Nusa indah putih plants based on gene matK and to characterize the matK of Nusa indah putih plant using in-silico analysis had been done. Isolation of DNA from Nusa indah putih plant was conducted by manual procedures of InnuPrep Plant DNA kit, followed by amplification using Polymerase Chain Reaction (PCR) method using matK-1RKIM-f as forward primer and matK3FKIM-r as reverse primer then electrophoresis and sequenced. Nusa indah putih plants sequencing produced a high-quality chromatogram produce, with a length of $843 \mathrm{bp}$ sequences. Results of in-silico analysis showed that matK Nusa indah putih plant is a base, stable, and wellinteracted with water.
\end{abstract}

\section{K E Y W O R D S}

nusa indah putih plant

matk

Barcode DNA

in-silico

\begin{tabular}{l} 
TERSEDIA ONLINE \\
\hline 5 Juli 2015
\end{tabular}

\section{Pendahuluan}

Nusa indah putih (Mussaenda frondosa $L$ ) dari famili Rubiaceae tumbuh di berbagai tempat, dan dapat digunakan dalam pengobatan tradisional. Masyarakat menggunakan tanaman ini dengan cara meminum air rebusan daun, bunga, atau akar untuk mengobati berbagai macam penyakit (Heyne, 1987). Ekstrak daun nusa indah putih mengandung sitosterol (Dalimartha, 2009), sedangkan batang memiliki aktifitas antimikroba (Jayasinghe et al., 2002). Teknologi genetika saat ini telah berkembang, sehingga dapat membantu penelitian khususnya di bidang biokimia, misalnya teknologi deoxyribonucleic acid (DNA) barcoding yang didasarkan pada metode identifikasi spesies mahluk hidup dengan menggunakan potongan DNA pendek (Hebert et al., 2003).

Potongan DNA pendek standar yang digunakan dalam penentuan barcode tumbuhan, adalah gen ribulosa-1,5-bifosfat karboksilase ( $\mathrm{rbcl}$ ) dan gen maturase K (matK) (Kress et al., 2005). Gen matK lebih sulit diamplifikasi tetapi memberikan resolusi yang lebih tinggi dalam membandingkan spesies tumbuhan, sedangkan gen rbcl lebih mudah 
diamplifikasi, akan tetapi resolusinya rendah untuk dapat membedakan beberapa spesies yang berkerabat dekat (Hollingsworth et al., 2009). Oleh karena itu, pada penelitian ini digunakan gen matK sebagai gen penanda.

\section{Metode}

\subsection{Material}

Peralatan yang digunakan dalam penelitian ini adalah alat-alat gelas, hot plate, tabung Eppendorf, mikropipet, termoblok, mikrosentrifugasi, alat PCR (Biometra T-personal, Jerman), elektroforesis, spektrofotometer UV-Vis, UV-Transiluminator dan Lemari pembeku (freezer).

Bahan yang digunakan adalah daun nusa indah putih segar yang diperoleh dari kelurahan Paal 4 Manado. Kit untuk isolasi DNA tanaman menggunakan InnuPREP Plant DNA kit (Analytik Jena), primer forward dan reverse, master mix untuk PCR (5x Ready-to-Load Master Mix), agarosa, akuades, dan bufer Tris-borat-EDTA (TBE).

\subsection{Prosedur}

\subsubsection{Isolasi DNA Total Tanaman Nusa indah putih}

Sampel daun nusa indah putih yang masih segar dipotong dengan ukuran kira-kira 5 x $5 \mathrm{~mm}$ dan digerus dalam tabung Eppendorf. Selanjutnya sampel daun nusa indah putih yang sudah disiapkan dalam tabung Eppendorf ditambahkan lysis solution sebanyak $300 \mu \mathrm{L}$ dan proteinase $\mathrm{K}$ sebanyak $25 \mu \mathrm{L}$ dengan menggunakan mikropipet dan diinversikan beberapa kali agar homogen. Setelah itu, diinkubasi selama 45 menit pada suhu $55{ }^{\circ} \mathrm{C}$ menggunakan termoblok dan diinversikan kembali setiap 10 menit. Selanjutnya sampe dimasukkan ke dalam prefilter untuk difiltrasi, lalu disentrifugasi pada $12.000 \mathrm{rpm}$ selama 1 menit. Filtrat yang diperoleh ditambahkan binding solution sebanyak $200 \mu \mathrm{L}$ dan dicampurkan. Setelah itu, filtrat dituangkan ke dalam spin filter untuk difiltrasi kembali, lalu disentrifugasi pada $12.000 \mathrm{rpm}$ selama 1 menit. Filtrat dibuang, dimasukkan spin filter ke dalam receiver tube dan ditambahkan dengan washing solution HS sebanyak $500 \mu \mathrm{L}$ dan disentrifugasi $12.000 \mathrm{rpm}$ selama 1 menit dan difiltrasi kembali menggunakan spin filter. Setelah itu, ditambahkan washing solution MS sebanyak $750 \mu \mathrm{L}$ dan disentrifugasi $12.000 \mathrm{rpm}$ selama 1 menit. Selanjutnya, filtrat dibuang dan dimasukkan kembali spin filter ke dalam receiver tube dan disentrifugasi $12.000 \mathrm{rpm}$ selama 1 menit. Spin filter dipindahkan ke dalam tabung Eppendorf dan ditambahkan dengan elusion buffer sebanyak 100 $\mu \mathrm{L}$ dan didiamkan selama 1 menit pada suhu ruang. Selanjutnya disentrifugasi $10.000 \mathrm{rpm}$ selama 1 menit. Sampel DNA disimpan di dalam freezer bersuhu $-10^{\circ} \mathrm{C}$.

\subsubsection{Amplifikasi gen matK dengan Polymerase Chain Reaction (PCR) (Kolondam et al., 2012).}

Reaksi PCR dilakukan untuk amplifikasi gen matK menggunakan primer forward matK-3F (5'CGT ACA GTA CTT TTG TGT TTA CGA G-3') sebanyak 1 $\mu \mathrm{M}$, primer reverse matK-1R (5'-ACC CAG TCC ATC TGG AAA TCT TGG TTC-3') sebanyak $1 \mu \mathrm{M}$. Reaksi PCR dilakukan dalam volume total $25 \mu \mathrm{L}$ yaitu terdiri dari DNA templat $2 \mu \mathrm{L}$, firepol Master Mix $5 x 5 \mu \mathrm{L}$, primer forward $1 \mu \mathrm{L}$, primer reverse $1 \mu \mathrm{L}$, dd $\mathrm{H}_{2} \mathrm{O} 16$ $\mu \mathrm{L}$. Denaturasi awal dilakukan pada suhu $95{ }^{\circ} \mathrm{C}$ selama 2 menit. Denaturasi dilakukan pada suhu $95{ }^{\circ} \mathrm{C}$ selama 30 detik. Penempelan primer (annealing) dilakukan pada suhu $50{ }^{\circ} \mathrm{C}$ selama 30 detik. Reaksi polimerisasi dilakukan pada suhu 72 ${ }^{\circ} \mathrm{C}$ selama 1 menit. Siklus ini dilakukan sebanyak 35 kali.

Hasil PCR berupa fragmen DNA kemudian dielektroforesis menggunakan gel agarosa $1 \%$ dan divisualisasi dengan uv-transiluminator. Sampel hasil PCR selanjutnyya disekuensing.

\subsubsection{Pengolahan dan Analisis Data Urutan Nukleotida secara In-silico}

Kromatogram DNA hasil sekuensing disunting menggunakan software Geneious v5.6. Bagian awal hasil kromatogram DNA tersebut dihapus kira-kira $30 \mathrm{bp}$ dan untuk pembacaan nukleotida yang keliru diperbaiki berdasarkan tingkat keakuratan yang terbaca.

Hasil sekuensing yang menggunakan primer reverse dilakukan proses reverse dan complement (Drummond et al., 2012). Untuk keakuratan amplifikasi gen target yang diuji yaitu gen matK, maka diidentifikasi melalui BOLD (Barcode of Life Database) Systems (www.boldsystems.org) (Ratnasingham dan Hebert, 2007). Hasil suntingan sekuens matk nusa indah putih, selanjutnya dianalisis menggunakan Basic Local Alignment Search Tool (BLAST) untuk membandingkan urutan sekuens matK tanaman nusa indah putih dengan kerabat terdekat di GenBank (http://www.ncbi. nlm.nih.gov/). Selanjutnya, dilakukan penjajaran urutan nukleotida dari tumbuhan tersebut. Setelah itu, dilakukan analisis in-silico terhadap matK dari 9 kerabat terdekat nusa indah putih, yang meliputi analisis urutan asam amino dan sifat fisika-kimia protein matK tanaman nusa indah putih dengan menggunakan program ProtParam (http://expasy. org/protparam/).

\section{Hasil dan Pembahasan}

\subsection{DNA Total Tanaman Nusa Indah Putih}

DNA total Tanaman nusa indah putih diperoleh setelah melalui proses isolasi DNA yang telah dilakukan dan menghasilkan larutan jernih yang berwarna kuning muda kehijauan. Isolasi DNA total dilakukan untuk mengamplifikasi gen target matk yang terdapat dalam kloroplas. Gambar 1 
menunjukan DNA total dari tanaman nusa indah putih.

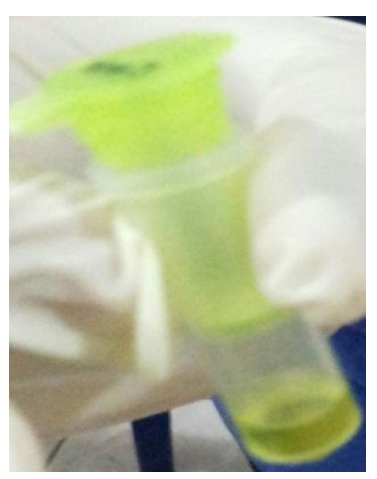

Gambar 1. DNA total tanaman nusa indah putih

Hasil PCR tanaman nusa indah putih setelah dielektroforesis menghasilkan fragmen DNA yang ditunjukkan oleh elektroforegram yang tertera pada Gambar 2. Pita DNA yang teramplifikasi yaitu sebanyak 864 bp untuk primer forward dan 862 bp untuk primer reverse. DNA hasil PCR dari tanaman nusa indah putih selanjutnya disebut gen matK tanaman nusa indah putih.

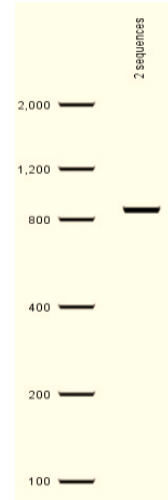

Gambar 2. Elektroforegram hasil amplifikasi matK dengan PCR

\subsection{Barcode DNA dan Karakteristik Asam Amino}

Sekuensing gen matK tanaman nusa indah putih menghasilkan kromatogram yang berkualitas tinggi, dengan nilai High Quality (HQ\%) kromatogram yang terbaca pada Geneious v5.6 adalah $>92,7 \%$. Sekuens matk yang teramplifikasi telah dihapus \pm 30 bp untuk primer forward dan primer reverse, sehingga panjang sekuens menjadi 843 bp. Gambar 3 menunjukkan hasil sekuensing gen matk tanaman nusa indah putih, baris bagian atas menunjukan nukleotida dan baris bagian bawah yang berwarna menunjukan asam amino. Pada Gambar 3 tidak ada kodon stop yang terbentuk di tengah-tengah sekuens, yang berarti bahwa hasil amplifikasi DNA yang dilakukan bersifat valid.

Sifat-sifat fisika kimia protein matK meliputi ukuran (asam amino dan urutan nukleotida), bobot molekul (Da), titik isoelektrik (pl), Indeks ketidakstabilan atau Instability Index (II), dan Grand Average hydropathy (GRAVY). Hasil analisis sifat fisika kimia protein matK tanaman nusa indah putih dengan menggunakan program ProtParam yang tersedia dalam situs http://www.expasy.org/ tools/protparam.html

Nilai pl teoritis dari protein matK tanaman Nusa indah putih adalah 9.53. Hal ini menunjukan bahwa Nusa indah putih bersifat basa, karena memiliki nilai pl lebih dari 7. Nilai pl didefinisikan sebagai $\mathrm{pH}$ dimana jumlah muatan negatif yang sama dengan jumlah muatan positif dari suatu protein. Nilai pl $<7$ bersifat asam dan $>7$ bersifat basa.

Indeks ketidakstabilan (Instability Index, II) menunjukan stabil tidaknya struktur dari protein. Protein yang tidak stabil memiliki indeks ketidakstabilan (II) > 40 dan semua protein yang stabil memiliki indeks ketidakstabilan < 40 (Guruprasad et al., 1990). Nusa indah putih memiliki indeks ketidakstabilan 37.75 sehingga protein tersebut bersifat stabil. Untuk indeks Grand Average hydropathy (GRAVY) protein matK Nusa indah putih memiliki nilai yang rendah (negatif). Kyte dan Dolittle (1982) mengemukakan bahwa protein yang memiliki nilai indeks GRAVY $<-0,4$ bersifat larut dalam air. Indeks GRAVY protein matK Nusa indah putih pada penelitian ini memiliki nila $<-0,4$ yang berarti dapat berinteraksi baik dengan air (hidrofilik).

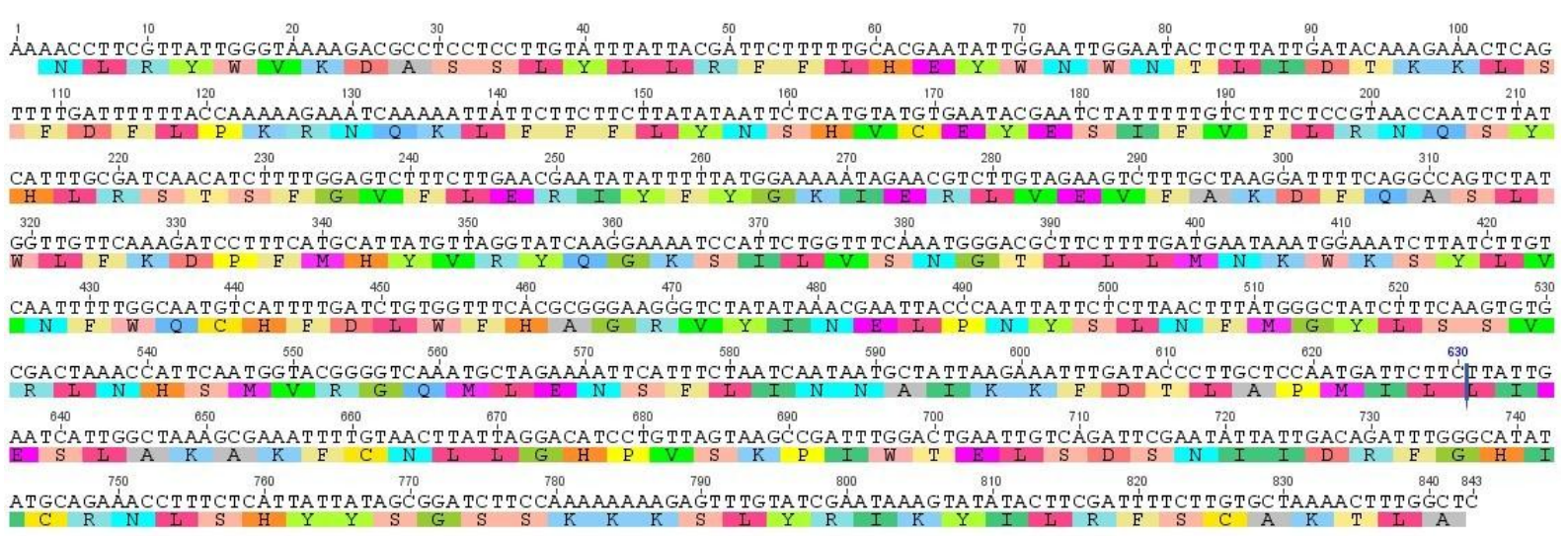

Gambar 3. Barcode DNA tanaman nusa indah putih 


\section{Kesimpulan}

Gen matK Mussaenda frondosa yang diamplifikasi dengan PCR memiliki urutan nukleotida 843 bp. Karakteristik fisika kimia protein matK Mussaenda frondosa adalah bersifat basa, stabil, dan berinteraksi baik dengan air.

\section{Daftar Pustaka}

Dalimartha, S. 2009. 36 Resep Tumbuhan Obat Untuk Menurunkan Kolestrol. Penebar Swadaya, Jakarta.

Guruprasad, K., B. V. B. Reddy, and M. W. Pandit. 1990. Correlation Between Stability of A Protein and Its Dipeptide Composition: A Novel Approach for Predicting In Vivo Stability of A Protein From Its Primary Sequence. Protein Engineering. 4: 155-161.

Hebert, P.D.N., N.A. Cywinska, S.L. Ball and J.R. de Waard. 2003. Biological identifications through DNA barcodes. Proc. Roy. Soc. B-Biol. Sci. 270: 313-321.
Heyne, K. 1987. Tumbuhan Berguna Indonesia. Jilid III. Yayasan Sarana Wanajaya, Jakarta.

Hollingsworth, P. M., L. L. Forrest, J. L. Spouge, M. Hajibabaei, and R. Ratnasingham. 2009. A DNA Barcode for Land Plants. Proc. Natl. Acad. Sci. USA. 106: 12794-97.

Jayasinghe, L. B., C. P. Jayasooriya. 2002. Bandara BMR. Antimicrobial activity of some Sri Lankan Rubiaceae and Meliaceae. Fitoterapia. 73(5): 424-7.

Kolondam, B. J., E. Lengkong dan J. Polii-Mandang. 2012. Barcode DNA Berdasarkan Gen rbcL dan matK Anggrek Payus Limondok (Phalus tancarvilleae). Bioslogos. 2: 55-62.

Kress, W. J., K. J. Wurdack, E. A. Zimmer, L. A. Weigt and D. H. Janzen. 2005. Use of DNA Barcodes to Identify Flowering Plants. PNAS. 102: 83698374.

Kyte, J. and R. F. Doolittle. 1982. A Simple Method for Displaying The Hydropathic Character of a Protein. J. Mol. Biol. 157: 105-132. 